\title{
Can Tempeh be Greenly Marketed by the Indonesian Tempeh Movement (ITM)?
}

\author{
Amadeus Driando Ahnan ${ }^{1}$, Wida Winarno ${ }^{2}$ and Marthin Nanere ${ }^{3}$ \\ ${ }^{1,2}$ Indonesia Tempeh Movement, Indonesia \\ ${ }^{3}$ School of Business, La Trobe University, Bendigo, Australia \\ m.nanere@latrobe.edu.au ${ }^{3}$
}

\begin{abstract}
The Indonesian Tempe Movement (ITM) has been green-marketing a 300year-old food from Indonesia to gain international recognition, earning 10,000 followers in addition to major public figure and governmental supports. The main purpose of this article is to introduce and promote Tempeh and ITM using the concept of green marketing. Tempeh, a soy-based fermented food, has been predicted to be potential to provide the world's ever-growing needs of affordable, nutritious, and sustainable protein sources. Compared to beef, tempeh contains similar amount and quality by producing just a fifth of total emission and consuming only tenth of total energy, on top of being sold at up to 12 times cheaper. Compiling such scientific data, the non-profit organization (ITM) green-markets the movement with aims to get people joining in sharing the knowledge, hence giving people access to affordable, nutritious, and sustainable protein source. In order to achieve the mission of ITM, marketing mix approach (4P) has been adopted. Tempeh as a new product, based on scientific research and development, has now been created using a tempeh-making technique that is greener by conserving up to $50 \%$ of water. Tempeh chips are also made of locally grown organic soybeans and handmade by underemployed individuals. The price is set up to cover the associated costs including the environmental and social costs. Tempeh, for example is also environmentally friendly. Bananas leaves are used to cover the Tempeh. Place of distribution include local market and online healthy snacks shop. The main promotion is mainly through the social media. The movement wraps its green and sustainability message through workshops, tempeh chips, educational videos, and campaigns. To sum up, the Indonesian Tempe Movement's practices provide insights on science-based green marketing that incorporates environmental, social, and economical aspect.
\end{abstract}

Keywords: Tempeh, Indonesian Tempeh Movement, Marketing Mix, Green marketing

\section{Introduction}

One of the major trends in modern business has been green marketing[1]. An increase in the consumer's awareness concerning environmental issues along with stricter regulations introduced by governments, particularly in industrially developed countries, has led to the demand for green or ecological products and sustainable business activities [2]. At the same time, the green movement became successful on the political arena of many European countries [3].

The green marketing of products and services has gradually become an important jargon and concept in emerging markets in Asia including Indonesia. By adopting resource conserving and environmentally friendly strategies in all stages of the value chain, the not for profit and profit companies can address the growing 
environmental concerns. For example, in Australia, business firms face social and legal pressure to adopt environmentally-friendly business strategies. As a result, many companies responded to the pressures and adopted environmentally-friendly strategies.

In Indonesia, some companies have been pursuing green marketing strategies for some time now. Many companies have launched program to contain damage to the environment and project themselves as environmentally-friendly companies. The Indonesian companies and consumers are increasingly becoming environment conscious and many environmental management initiatives have been launched by different segments of the society. Several companies have launched advertising campaigns to project environmentally conscious corporate images and promote products that are less harmful to the environment.

Research indicates that consumers are voicing their concern for the environment into their purchasing behaviour in different ways. There is a growing amount of evidence suggesting that consumers are choosing products or avoiding others based on their impact on the environment [4][5]. Others suggest that not only do consumers desire to purchase products that are less environmentally harmful, but also are willing to pay more [6][7].

Around the world, there has been an increasing number of companies, which have introduced green products. The degree to which green marketing has been incorporated into a company's marketing strategies has varied between companies. This may include modifying existing products to be less environmentally harmful. This is the case of Indonesian Tempe Movement, which has invented a new and innovative way of making tempeh, which is more environmentally friendly.

Indonesian Tempe Movement (ITM) is a non-profit organization that aims to give people access to affordable, nutritious, and sustainable protein source through promoting tempeh. It was founded in 2014 by tempeh-focused food scientists to translate scientific findings into activities that educate society about tempeh, connect stakeholders in the tempeh industry, and empower people through social entrepreneurship. ITM has reached 9 countries and 6 continents by 2018 with its initiatives including tempeh workshop, tempeh talks, culinary events, festivals, scientific conferences, social media campaigns, and book publishing.

As sustainability being one of the ITM's core messages, ITM conveys green marketing for the movement in general and some products in particular.

The objectives of this article include:

1. Analysing the green marketing strategies of Indonesian Tempeh Movement (ITM)

2. Evaluating the impact of the green marketing strategies of Indonesian Tempe Movement (ITM)

\section{Literature Review}

Based on the literature review on green marketing, there are four main research areas of categories. They include the relevance of green marketing, the impact of green marketing on firms' performance and competitiveness, the factors considered by consumers when purchasing green products and finally improving effectiveness of green marketing.

In the context of Asian countries, during the 1990s companies faces increasing environmental challenges due to pressure coming from government, industry groups and competitors. The increasing influences of communities on companies, the high cost of complying with environmental regulations, and changing consumer attitudes are forcing companies to become environmentally conscious.

It is suggested that properly designed environmental standards can trigger innovations that actually lower the total cost of a product or improve its value making companies more competitive. These innovations allow companies to use raw material, energy and labour more efficiently. However, poll findings show that a majority of US consumers are environmentally conscious but their concerns are not transferred into their purchase decisions [8].

In order to improve the impact of green marketing strategies, it is suggested that companies should build formal and informal alliances with environmental groups to improve the credibility and give a strategic direction to their green marketing programs.

\section{Methodology}

The green marketing strategies and impacts were obtained by examining internal documents and by conducting in-depth interviews with the ITM co-founders, staffs and customers. 


\section{Findings}

\section{a. Green marketing of Tempeh}

Based on the depth interviews, it shows that there are opportunities and threats for green marketing of tempeh in Indonesia.

\section{Opportunities}

Since environmental problems facing the people are getting more serious every day, it becomes important to promote environmental consciousness. Fast economic growth without prevention or control of potentially environmental problems, could eventually lead to more environmental problems. Thus, the internal societal pressures and growing compulsion within the Indonesian society to solve present environmental problems will give rise to demand for environmentally friendly products ("green" Tempeh) and business strategies for ITM.

There is a growing external pressure for eco-friendly products and production methods. Environmentallyfriendly products are bound to find wider market opportunities in the global context by preventing the possibilities that other countries may use their environmental standards as trade barriers against exports. Tempeh can enjoy the competitive advantage in terms of brand recognition and image both in the domestic and foreign markets. In term of partnership, this also opens the access to connecting with other organizations that have particular consideration or idealism in sustainability.

\section{Threats}

Companies allocate low priority to green marketing. At present, there are many environmental problems which need to be solved and in the short term only few problems can be focused on. The benefits of green marketing may not be outstanding to be clearly perceived by the customers.

At the moment there is not enough pressure felt by environment damaging products to shift to more environmentally-friendly products in Indonesia. Because of lack of awareness and understanding, not many customers are sensitive to the potential damage to the environment caused by conventional products. Since results of green marketing are not obvious in the short term, it is difficult to influence the target group to become environmentally aware. The positive impact of green marketing is not felt to be real by many groups. For example, there are perceptual problems associated with refilling of products. Many consumers do not accept refill products because they are concerned about hygiene when refilling products. Another example, the cost of recycled paper is higher than prime paper, which discourages people from using recycled paper.

In this regards, the Indonesian Tempe Movement's green marketing strategy acts as an educative initiative that will serve more educated consumers in Indonesia to notice the value of green marketing down the line.

Another potential threat of the green marketing initiated by the Indonesian Tempe Movement is the cultural barrier. Tempeh has been known as a traditional food that is identical with traditional cuisines. Modifying its branding that is cored at its production method could be perceived as a compromise of cultural practice.

\section{b. Indonesia Tempeh Movement \\ Product}

Indonesia Tempeh Movement (ITM) has a few products including both main product and derivative product. The main product or service is to introduce tempeh to society through training, hands-on workshop, masterclass and words of mouth. Tempeh chip is a derivative product produced by the ITM, and this product can testify to the society the process of how to make tempeh hygienically in a small industry scale. Apart from this product, the ITM also produces fresh tempeh, tempeh starter, a natural preservative for tempeh, merchandises including tshirt, tote bag, apron and tempeh books. At the moment, the ITM is in the process to create more innovative derivative products such as tempeh masker, and tempeh noodle.

The tempeh training offered by the ITM employs a specific method taking into account hygiene and sanitation factor, it is also environmentally friendly. This training does not only consider the environment by using less water and fuel, but also minimizes waste. In minimizing the use of water and fuel, the ITM has been supported by MBRIO R\&D to develop a fermented liquid made from local fruit in order to shorten the tempeh making process time.

The liquid is used in the process of soaking the soybeans, in which the soybeans can be soaked for a longer time without being decay, and the soybeans are not required to be boiled and washed many times. Consequently, the use of fuel and water is less, and at the same time, less waste is produced. 
Waste from this tempeh making process, including the used water, the soybean skins can be used to feed animals, or as an organic fertilizer. The ITM tempeh training makes use of bamboo produced by local farmers. Besides, the ITM also teaches how to make tempeh using local leafs from different places in Indonesia to cover tempeh, including coklat leaf, simpur leaf (from Belitung), bamboo leaf, waru and jati leaf (from central Jawa), sagu and bawang utan leaf (from Papua), and off course banana leaf. Every local place in Indonesia can use local leaf's to cover the tempeh and other food. This covering leaf does not only contribute to the specific aroma of tempeh, but it is also environmentally friendly and preserves local wisdom.

\section{Price}

The price applied by the ITM is not only profit oriented, but it also considers the sustainability of the ITM activities. Cross subsidy is used for finance. For example, to run a social event in places where no charges are applied, such as training in the prison, rehabilitation centre, or villages, the finance can be sourced from the proceeds of tempeh chips and other merchandises.

The ITM products are sold with competitive prices using premium materials. For example, tempeh chips only use local soybeans produced by local farmers, as well as coconut oil produced by local company.

\section{Promotion}

For promotion, media social including facebook, instagram, twitter and website www.tempemovement.com are used. In addition, brochure, leaflet, infographic about tempeh, and public figures are also used to promote tempeh and the ITM. To minimise the production costs, promotional material are designed by the ITM and parties joined in voluntary basis in the context of a movement.

\section{Place}

The tempeh training has been conducted not only in places in Indonesia, but also in several different countries, including Australia, Holland and France. In Indonesia, this tempeh training has reached different segments of the market including marginalized people, such as prisoners, patients from drug rehabilitation centre, as well as high class people. The places to hold the training range from prisoners, schools and universities.

\section{Policies and practices}

The foundations of the green marketing strategy are called 4-Rs, including:

1 Recycle - the company collects all types of packaging for recycling.

2 Refill - all outlets provide product refill service

3 Reuse - the company encourages reuse of promotional material

4 Reduce - by reduction, the company has eliminated all unnecessary packaging. In the company office, environmentally-friendly practices such as energy conservation, efficient use of stationary, sharing of computers and transportation facilities have been established.

\section{Conclusions}

The answer to our title is yes, though in introduction stage, green marketing in Indonesia is characterized by opportunities and threats. The green marketing strategy of the Indonesian Tempe Movement serves as a platform for branding, education, and partnership to develop socially-conscious business.

Future research can explore factors that may influence the intention to consume "green tempeh" using a wellestablished Theory of Planned Behaviour. The outcome may be able to shed the light on how to strategically communicate the message to the audience about the "green tempeh", which is environmentally friendly.

\section{References}

[1] C. Peattie, Crane, and A., "Green marketing: legend, myth, farce or prophecy?," Qual. Mark. Res. An Int. J., vol. 8, no. 4, pp. 357-370, 2005.

[2] "Developing green product: learning from stakeholders," Asia Pacific J. Mark. Logist., vol. 10, no. 1, pp. 22-43, 1998.

[3] S. Majeed, "The Impact of Competitive Advantage on Organizational Performance," Eur. J. Bus. Manag., vol. 1, no. 2, pp. 48-62, 2011.

[4] G. H. G. McDuogall, "The green movement in Canada: implications for marketing strategy," J. Int. Consum. Mark., vol. 15, no. 3, pp. 69-87, 1993. 
[5] J. J. Davis, "Strategies for environmental advertising,” J. Consum. Mark., vol. 10, no. 2, pp. 19-36, 1993.

[6] C. D’Souza, M. Taghian, P. Lamb, Peretiakos, and R., "Green products and corporate strategy: an empirical investigation," Soc. Bus. Rev., vol. 1, no. 2, pp. 144-157, 2006.

[7] C. D'Souza, M. Taghian, G. S. Mort, Gilmore, and A., "An evaluation of the role of green marketing and a firm's internal practices for environmental sustainability," J. Strateg. Mark., vol. 23, no. 12, pp. 600 $615,2014$.

[8] J. A. Roberts, "Green consumers in the 1990s: profile and implications for advertising," J. Bus. Res., vol. 36, no. 3, pp. 217-3, 1996. 